\title{
KARAKTERISTIK DAN SIKAP WANITA PEKERJA SEKSUAL TIDAK LANGSUNG DALAMKEIKUTSERTAAN SKRINING INFEKSI MENULAR SEKSUAL (IMS) DI KOTA SALATIGA.
}

\author{
Miftakhuljannah Ernestine ${ }^{1)}$, Rizky Amelia ${ }^{2)}$, Triana Sri Hardjanti ${ }^{3)}$ \\ E-mail : miftaa.ernestine@gmail.com
}

\begin{abstract}
Keyword: Knowledge, Attitude, Partisipation, STI screening

1).2).3) civitas akademika Poltekkes Semarang

Infeksi menular seksual (IMS) sampai saat ini masih merupakan masalah kesehatan masyarakat di seluruh dunia, baik di negara maju maupun di negara berkembang. Peningkatan insiden IMS dan penyebarannya di seluruh dunia tidak dapat diperkirakan secara tepat. Di beberapa negara disebutkan bahwa pelaksanaan program penyuluhan yang intensif akan menurunkan insiden IMS atau paling tidak insidennya relatif tetap. Namun demikian, di sebagian besar negara insiden IMS relatif masih tinggi dan setiap tahun beberapa juta kasus baru beserta komplikasi medisnya antara lain kemandulan, kecacatan, gangguan kehamilan, gangguan pertumbuhan, kanker bahkan juga kematian memerlukan penaggulangan, sehingga hal ini akan meningkatkan biaya kesehatan (Claudia, 2013).

Kasus baru infeksi menular seks (IMS) Provinsi Jawa Tengah tahun 2011 ini menjadi 0,7 per 1.000 penduduk perempuan. Jumlah tersebut dari tahun ke tahun semakin meningkat.Jumlah kasus baru IMS di Kota Semarang pada tahun 2010 berdasar-

kan pelaporan sebanyak 3 per 1.000 penduduk perempuan. Berdasarkan laporan bulanan kasus infeksi menular seks dengan menggunakan pendekatan laboratorium didapatkan gonore, suspek gonore, servisitis mencapai 84,78\% (1650 kasus IMS) untuk kelompok berisiko (Nazarwin, 2016).

Jumlah kasus IMS di Kota Salatiga dari tahun ke tahun semakin meningkat. Meskipun demikian kemungkinan kasus yang sebenarnya di populasi masih banyak yang belum terdeteksi. Program Pencegahan dan Pemberantasan Penyakit Menular Seksual mempunyai target bahwa seluruh kasus IMS yang ditemukan harus diobati sesuai standar. Di Kota Salatiga semua kasus IMS yang ditemukan sudah ditangani.Tercatat bahwa pada tahun 2012 sebanyak 953 kasus baru yang ditemukan.Pada tahun 2013 sebanyak 1337 kasus baru yang ditemukan.Hal tersebut menunjukkan bahwa terjadi peningkatan jumlah kasus baru yang ditemukan cukup banyak (Dinas Kesehatan Salatiga, 2013).

Berdasarkan data di Puskesmas Sidorejo Lor Kota Salatiga pada tahun
\end{abstract}


2013 kegiatan skrining IMS jumlah peserta $1486(61,9 \%)$, dengan positif IMS 1259 (52,5\%). Sedangkan data Tahun 2014 sampai Bulan November 2014 kegiatan skrining IMS jumlah peserta $1532(63,8 \%)$, dengan positif IMS 1176 (49\%), hal ini menunjukan penurunan kasus IMS namun angka IMS ini sendiri masih cukup tinggi. Sedangkan data pada Tahun 2014 Bulan Agustus jumlah kunjungan pemandu karaoke sebanyak 62 (31\%), dengan positif IMS sebanyak 48 (24\%), Bulan September jumlah kunjungan pemandu karaoke sebanyak 173 (86,5\%), dengan positif IMS sebanyak 105 (52,5\%), Bulan Oktober jumlah kunjungan pemandu karaoke sebanyak 168 (84\%), dengan positif IMS sebanyak $123(61,5 \%)$, Bulan November jumlah kunjungan pemandu karaoke sebanyak 104 (52\%), dengan positif IMS 91 (45,5\%). (Novita, 2015)

Berdasarkan data dari Puskesmas yang ada pada tahun 2016 tercatat sebanyak 250 Wanita Pekerja Seksual Tidak Langsung (WPS-TL) yang berada di wilayah Puskesmas Sidorejo Lor. Berdasarkan studi pendahuluan pada tanggal 24 Februari 2017 di Desa Sarirejo, terdapat perkumpulan paguyuban yang beranggotakan 54 WPSTL sebagai perwakilan setiap tempat karaoke dan 10 pengurus paguyuban.Upaya yang dilakukan oleh Dinas Kesehatan Kota Salatiga yang bekerjasama dengan Puskesmas Sidorejo Lor dan LSM sekitar untuk mencegah penularan IMS dan HIV yaitu dengan melakukan Skrining IMS dan VCT

Penelitian ini menggunakan metode korelasi dengan pendekatan cross sectional. Populasi dalam penelitian ini adalah anggota paguyuban sebanyak 54 orang. Sampel diambil dengan cara total sampling yaitu dengan yang rutin dilakukan. Skrining IMS merupakan suatu upaya atau deteksi dini yang dilakukan berdasarkan pemeriksaan atau prosedur lain untuk kasus penyakit menular seksual atau infeksi menular seksual (Romauli, 2012). Skrining IMS ini dilakukan setiap 1 bulan sekali yaitu pada hari Selasa dan Kamis. Sedangkan VCT (Voluntary Counseling and Testing) adalah proses konseling pra testing, konseling post testing, dan testing HIV secara sukarela yang bersifat confidential dan secara lebih dini membantu orang mengetahui status HIV. VCT ini dilaksanakan setiap tiga bulan sekali.

Kegiatan skrining IMS di Puskesmas Sidorejo Lor dilaksanakan dengan tidak memungut biaya (gratis). Bagi WPS-TL yang ditemukan terjangkit IMS akan dilakukan tindak lanjut yaitu dengan pemberian konseling dan pemberian terapi oleh dokter. Hal tersebut dilakukan dengan maksud agar tidak terjadi penularan ke pelanggan lain ataupun pekerja lain sehingga dapat menekan angka kejadian IMS pada wilayah Kota Salatiga yang tergolong tinggi.

Tujuan penelitian ini adalah untuk mengetahui karakteristik dan hubungan antara sikap dengan keikutsertaan skrining Infeksi Menular Seksual (IMS) pada Wanita Pekerja Seksual Tidak Langsung (WPS-TL) di wilayah Puskesmas Sidorejo Lor Kota Salatiga.

\section{METODE PENELITIAN}

mengambil seluruh anggota populasi sebagai responden atau sampel. Instrument yang digunakan adalah kuesioner tentangumur, pendidikan, sikap, dan keikutsertaan.Uji normalitas data menggunakan uju Kolmogorov 
SmirnovZ.Analisa data yang digunakan adalah dengan menggunakan analisis Chi-Square.

\section{HASIL DAN PEMBAHASAN}

Tabel 1

Distribusi data karakteristik berdasarkan umur

\begin{tabular}{ccc}
\hline Kategorumur & $\begin{array}{l}\text { Frekufr } \\
\text { frek }\end{array}$ & $\begin{array}{l}\text { Prosent } \\
(\%)\end{array}$ \\
\hline$<2>35$ tahun & 22 & 40,7 \\
20-35 tahun & 3259,3 & 59,3 \\
\hline Jumlah & 54 & 100 \\
\hline
\end{tabular}

Kriteria responden berdasarkan umur dibagi menjadi dua kategori yaitu yang kurang dari 20 tahun atau lebih dari 35 tahun dan 20 sampai 35 tahun. Peneliti menggunakan dua kategori tersebut untuk menilai apakah responden termasuk dalam kategori usia reproduksi sehat atau usia reproduksi tidak sehat. Dari hasil penelitian didapatkan $32 \quad(59,3 \%)$ responden memiliki usia reproduksi sehat sedangkan $22(40,7 \%)$ responden memiliki usia reproduksi tidak sehat. Dari hasil uji normalitas didapatkan bahwa data umur berdistribusi normal, yang berarti bahwa umur responden rata-rata sama. Hal tersebut sejalan dengan penelitian yang dilakukan oleh Reynera di lokalisasi Tegalrejo, Bergas, Kabupaten Semarang tahun 2013 yang menunjukkan sebanyak 34 responden $(56,7 \%)$ memiliki usia reproduksi sehat.

Dari hasil penelitian yang telah dilakukan memperlihatkan bahwa mayoritas reponden memiliki usia reproduksi sehat. Reproduksi yang sehat sangat mempengaruhi kesehatan organ reproduksi itu sendiri, sehingga responden dapat menjaga kesehatan reproduksinya.
Tabel 2

Distribusi data karakteristik berdasarkan pendidikan

\begin{tabular}{lcc}
\hline Kategori & $\begin{array}{c}\text { Frekuen } \\
\text { si }\end{array}$ & $(\%)$ \\
\hline $\begin{array}{l}\text { Pendidikan Dasar (SD- } \\
\text { SMP) }\end{array}$ & 20 & 37 \\
$\begin{array}{l}\text { Pendidikan Menengah } \\
\text { (SMA) }\end{array}$ & 34 & 63 \\
$\begin{array}{l}\text { Pendidikan Tinggi } \\
\text { (Akademi/PT) }\end{array}$ & 0 & 0 \\
\hline Jumlah & 54 & 100 \\
\hline
\end{tabular}

Karakteristik responden berdasarkan pendidikan, pendidikan responden sebagian besar adalah pendidikan menengah atau SMA yaitu sebanyak 34 (63\%) responden. Hal ini sejalan dengan penelitian yang dilakukan oleh Rahmadhan di Kecamatan Lima Puluh Pekanbaru pada WPS-TL tahun 2016 bahwa ditemukan sebagian besar responden memiliki pendidikan terakhir SMA. Hal ini kemungkinan disebabkan karena sulitnya mendapat pekerjaan serta mudahnya mendapatkan uang yang banyak dalam waktu yang singkat dengan menjadi WPS-TL.

Tingkat pendidikan terakhir menjadi faktor penting pada skrining IMS, karena tingkat pendidikan yang rendah akan mempengaruhi pengetahuan tentang IMS dan pencegahannya. Hal ini dapa dilihat dari hasil penelitian yang mengatakan bahwa sebagian besar responden memiliki pengetahuan yang cukup.

Tabel 3

Distribusi data sikap

Gambaran Sikap WPS-TL terhadap skrining IMS

\begin{tabular}{lll} 
Kategori & Freku & $(\%)$ \\
\hline
\end{tabular}




\begin{tabular}{ccc}
\hline & ensi \\
\hline Negatif & 19 & 29.6 \\
Positif & 35 & 70.4 \\
\hline Jumlah & 54 & 100 \\
\hline
\end{tabular}

Berdasarkan hasil penelitian, sebagian besar responden memiliki sikap positif yaitu sebanyak $35(70,4 \%)$ responden sedangkan $19 \quad(29,6 \%)$ responden memiliki sikap negatif. Hasil penelitian ini sejalan dengan yang dilakukan oleh Rahmadhan pada WPS-TL di wilayah Pekanbaru tahun 2016 tentang pemeriksaan pap smear dan IMS dengan prosentase sebanyak 18 orang $(58,1 \%)$ memiliki sikap positif. Hal ini disebabkan karena pemeriksaan pap smear dan IMS belum pernah dilakukan di daerah tersebut sehingga responden cenderung bersikap positif terhadap pemeriksaan pap smear dan IMS.

Berbeda dengan penelitian yang dilakukan oleh Suesti di Yogyakarta pada tahun 2013 pada WUS ditemukan mayoritas WUS meiliki sikap negatif dengan persentase 37,5\%. Hal tersebut disebabkan karena kurangnya penyuluhan yang dilakukan oleh tenaga kesehatan sehingga mayoritas responden tidak peduli dengan pemeriksaan.

\section{Tabel 4}

Distribusi data Keikutsertaan Skrining Gambaran Keikutsertaan Skrining IMS

\begin{tabular}{cll}
\hline Kategori & Frekuens & Prosentase \\
\hline Ya & 40 & 74.1 \\
Tidak & 14 & 25.9 \\
\hline Jumlah & 54 & 100 \\
\hline
\end{tabular}

Menurut Azwar (2007) penilaian sikap terdiri dari sikap positif yaitu kalimat yang bersifat mendukung atau memilih pada objek sikap dan sikap negatif yaitu yang bersifat tidak mendukung ataupun kontra terhadap objek sikap.Berdasarkan hasil penelitian diperoleh data bahwa responden yang mengikuti skrining IMS dalam 3 atau 6 bulan terakhir lebih banyak daripada yang tidak mengikuti skrining. Responden yang mengikuti skrining sebanyak $40(74,1 \%)$ dari 54 responden.

Hal tersebut tidak sejalan dengan penelitian yang dilakukan oleh Hastuti di resosialisasi Gambilangu Kendal tahun 2011 yang menunjukkan bahwa sebanyak 34 responden $(53,13 \%)$ tidak rutin mengikuti skrining IMS.

Tabel 5

Hubungan Sikap dengan Keikutsertaan Skrining Hubungan Sikap WPS-TL dengan Keikutsertaan Skrining IMS

\begin{tabular}{ccccccc}
\hline Sikap & \multicolumn{3}{c}{ Keikutsertaan Skrining } & \multicolumn{3}{c}{$\begin{array}{c}p \\
\text { value }\end{array}$} \\
\cline { 2 - 6 } & Ya & $\%$ & $\begin{array}{c}\text { Tid } \\
\text { ak }\end{array}$ & $\%$ & $\begin{array}{c}\text { Tota } \\
1\end{array}$ & \\
\hline Negatif & 9 & 47,37 & 10 & 52,63 & 19 & \\
Positif & 31 & 88,57 & 4 & 11,43 & 35 & 0,001 \\
\hline
\end{tabular}

Berdasarkan uji Chi-Square diperoleh nilai $\mathrm{p}$ value $=0.001$ pada taraf kepercayaan $5 \%$. Karena $\mathrm{p}$ value $=0.001$ kurang dari $0.05(0.00<0.05)$ sehingga $\mathrm{Ha}$ diterima yang menyatakan bahwa ada hubungan antara sikap WPS-TL tentang IMS dengan keikutsertaan skrining IMS.

Hal ini sesuai dengan penelitian yang dilakukan oleh Raisyifa (2010) yang mengatakan bahwa terdapat hubungan yang bermakna antara sikap dengan tindakan pencegahan IMS. Hal tersebut juga dapat dilihat dari data penelitian yang menunjukkan bahwa sebanyak $31(88,57 \%)$ responden yang 
memiliki sikap positif mengikuti pemeriksaan skrining. Karena semakin baik sikap yang dimiliki oleh seseorang akan semakin aktif juga keikutsertaannya dalam melaksanakan pemeriksaan skrining.

\section{SIMPULAN}

Berdasarkan penelitian Hubungan Antara Pengetahuan dan Sikap Dengan Keikutsertaan Skrining IMS pada WPS-TL di Wilayah Puskesmas Sidorejo Lor Kota Salatiga terhadap 54 responden dapat disimpulkan bahwa :

1. Sebagian besar responden memiliki usia reproduksi sehat $(20-35$ tahun) yaitu sebanyak $32(59,3 \%)$ responden.

2. Sebagian besar responden memiliki pendidikan menengah (SMA) yaitu sebanyak 34 (63\%) responden.

3. Sebagian besar responden memiliki sikap positif yaitu sebanyak $38(70,4 \%)$ responden.

4. Terdapat hubungan antara sikap WPS-TL dengan keikutsertaan skrining IMS. Semakin positif sikap yang dimiliki maka semakin baik keikutsertaan skrining IMS.

\section{SARAN}

Bagi responden diharapkan meningkatkan upaya pencegahan dasar dan melakukan pemeriksaan skrining IMS yang telah ditentukan oleh dinas kesehatan di Kota Salatiga bagi yang belum mengikuti skrining. Bagi Dinas Kesehatan dan Instansi Kesehatan Terkait dapat meningkatkan kualitas pelayanan melalui peningkatan ketrampilan tenaga kesehatan. Memberikan penyuluhan untuk meningkatkan sikap WPS-TL mengenai IMS dan pencegahannya sehingga WPS-
TL memiliki sikap yang positif untuk menikuti kegiatan skrining.

\section{UCAPAN TERIMAKASIH}

Terimakasih disampaikan kepada Keluarga tercinta yang tak pernah berhenti memberikan doa dan dukungan baik moril maupun materiil. Seluruh Civitas akademika yang selalu memberikan semangat satu sama lain dalam penyusunan naskah publikasi ini.

\section{DAFTAR PUSTAKA}

Arikunto, S. 2006. Prosedur Penelitian Suatu Pendekatan Praktik.

Aziz, A; Ade, W; Suyanto (2016). Hubungan Pengetahuan Dan Sikap Terhadap Tindakan Tentang Pap Smear Dan Inspeksi Visual Asetat Pada Wanita Pekerja Seksual Tidak Langsung Di Hotspot X Kecamatan Marpoyan Damai Pekanbaru Sebagai Deteksi Dini Kanker Serviks. Laporan Penelitian. Riau : Universitas Riau.

Azwar, S. 2010. Sikap Manusia. Yogyakarta : Pustaka Pelajar.

Burns, T.2005.Dermatologi Edisi 8, diterjemahkan oleh M. Anis Zakaria. Erlangga: Jakarta

Dahlan, M.S. 2013. Besar Sampel dan Cara Pengambilan Sampel dalam penelitian Kedokteran dan Kesehatan.Salemba Medika:Jakarta

Daily, S F; dkk.2007.Infeksi menular seksual (Edisi ketiga).Balai Penerbitan FKUI: Jakarta.

Davey, P.2005.At a glance Medicine.Diterjemahkan oleh Annisa Rahmalia \& Cut Novianti. Erlangga : Jakarta 
Dinkes Salatiga.Profil Kesehatan Sala tiga tahun 2013.2013. Salatiga.

Efendi, F \& Makhfudi. 2009. Keperawatan Kesehatan Komunitas: Teori dan Praktik dalam Keperawatan. Salemba Medika:Jakarta

Hastuti，L.D.2011.Faktor-faktor yang Berhubungan Dengan Keikutsertaan Skrining Penyakit Menular Seksual pada WPS di Resosialisasi Gambilangu Kabupaten Kendal Tahun 2011. Sripsi. Semarang: Universitas Negeri Semarang

Hayes, E. R \& Kee, J.L. 1996. Farma kologi, diteremahkan oleh Peter Anugerah.EGC:Jakarta

Ismail, A.2016.Analisis Tingkat Keter jangkitan IMS pada WPS di Resosialisasi Argorejo Semarang. Skripsi.Semarang:Universitas Islam Negeri Walisongo

Lapau, B.2013.Metode Penelitian Kesehatan: Metode Ilmiah Penulisan Skripsi, tesis, dan desertasi.Yayasan Pustaka Obor Indonesia:Jakarta.

Lusiana,N; Andriyani, R; Megasari, M. 2015. Buku Ajar Metodologi Penelitian Kebidanan Edisi 1 Cetakan1. Deepublish: Yogyakarta

Manuba, I.B.G.1998.Ilmu Kebidanan, Penyakit Kandungan dan Keluarga Berencana untuk Pendidikan Bidan.EGC:Jakarta

.2004. Penuntun Kepaniteraan Klinik Obstetri dan Ginekologi Edisi 2.EGC:Jakarta

Manuba, I.B.G; Manuba, I.A.C; Manuba, I.B.G.F.2007.Pengantar Kuliah Obstetri.EGC:Jakarta
Maulana, H.D.J.2009. Promosi Kesehatan.EGC:Jakarta

Notoatmodjo, S. 2012. a.Ilmu Kesehatan Masyarakat. Jakarta : Rineka Cipta. .2012.b. Promosi Kesehatan.Rineka Cipta:Jakarta

Prawihardjo, S.2006.Ilmu Kebidaan Edisi 3 Cetakan 8.Yayasan Bina Pustaka:Jakarta

Rahmadhan, R; Ade, W; Suyanto. 2016. Hubungan Pengetahuan dan Sikap Terhadap Tindakan Wanita Pekerja Seksual Tidak Langsung Tentang Papsmear dan Inspeksi Visual Asetat pada Sebagai Deteksi Dini Kanker Serviks Di Hotspot X Kecamatan Lima Puluh Pekanbaru, Vol. 3, No. 2 Oktober 2016. Laporan Penelitian. Pekanbaru.

Raisyifa, Mangguang, M.D, Reflita. 2010. Faktor-Faktor yang Berhubungan Dengan Tindakan Pencegahan Infeksi Menular Seksual Pada Pekerja Seks Komersial Di Lokalisasi Teleju Pekanbaru. Laporan penelitian.Pekanbaru

Raynera ,C; Wahyuni, S; Sumarni, S. 2013. Sikap Dengan Perilaku Pekerja Seks Komersial (Psk) Tentang Pencegahan Infeksi Menular Seksual (IMS). Laporan penelitian.Semarang : Poltekkes Kemenkes Semarang.

Russell ,Jesse \& Cohn, R .2012. Voluntary Counseling and Testing. Book on Demand.

Saputra, N; Widjanarko, B; Setyawan, H.2016. Faktor-Faktor Risiko Pada Host Dan Lingkungan Yang Berpengaruh Terhadap Kejadian Servisitis Pada PSK. 
Laporan Penelitian. Padang : Universitas Andalas.

Siregar, R.S.2002.Penyakit Jamur Kulit Edisi 2. EGC : Jakarta

Sridana, M.E\& Indrayani, A.W.2012. Karakteristik Pasien Infeksi Menular Seksual (IMS) Pada Puskesmas di Denpasar Selatan Periode Januari - Juni Tahun 2012. Laporan Penelitian. Denpasar : Universitas Udayana.

Suesti.2013.Hubungan Pengetahuan tentang Kanker Serviks dengan Minat Melakukan Pemeriksaan Inspeksi Visual Asam Asetat (IVA) di Dusun Soka, Mardikerjo, Tempel, Sleman.Jurnal
Kebidanan Keperawatan, Vol.9, No. 2. Yogyakarta: Stikes Aisyah.

Sugiarto, E.2015.Menyusun Proposal Penelitian Kualitatif :Skripsi dan Tesis.Suaka Medika:Yogyakarta

Sukardi.2009.Metodologi Penelitian Pendidikan.Bumi Aksara:Jakarta

Swarjana, I.K.2012. Metodologi Pene litian Kesehatan.Andi Ofset: Yogyakarta

Tambayong, J.2000. Patofisiologi Untuk Keperawatan. EGC: Jakarta

Wawan, A \& Dewi, M.2011.Teori dan Pengukuran Pengetahuan ,Sikap, dan Perilaku Manusia.Nuha Medika:Yogyakarta. 